\title{
A CONTRIBUIÇÃO DO TOTEM E TABU PARA A EVOLUÇÃO DA ESPÉCIE HUMANA
}

\section{LA CONTRIBUCIÓN DE TÓTEM Y TABÚ PARA LA EVOLUCIÓN DE LA ESPECIE HUMANA}

\author{
Joana Lúcia Alexandre Freitas
}

Universidade Federal do Espírito Santo - câmpus São Mateus

E-mail: joana.freitas@hotmail.com

\section{Resumo}

A partir de agora, você é convidado a viajar pelo mundo da Biologia para entender como Sigmund Freud, o pai da psicanálise, que tanto contribuiu para as descobertas do comportamento humano, também fez pesquisas que colaboraram para a investigação da evolução da espécie humana. 0 objetivo principal desse trabalho e identificar que fatores contribuíram para a evolução da espécie humana, em particular, o comportamento das primeiras tribos humanas que viviam na África, o qual está retratado em sua obra Totem e Tabu. Freud viveu na mesma época em que a sociedade científica estava descobrindo sua origem, sua História quanto espécie e desenvolvendo as teorias da evolução e foi um dos primeiros a concordar com os pressupostos de Charles Robert Darwin, enquanto que a maioria dos estudiosos da época achincalhava-o. Freud descreveu os comportamentos das primeiras tribos humanas que, muito provavelmente, contribuíram para evitar a extinção do Homo sapiens. Tais comportamentos ainda regem os costumes e valores de nossa sociedade, e assim continuam colaborando para controlar o fluxo de alelos letais ${ }^{1}$ na espécie humana.

Palavras-chave: evolução da espécie humana. Freud e biologia. evolução. variabilidade genética.

\section{Resumen}

A partir de ahora, se le invita a viajar por el mundo de la biología para entender cómo Sigmund Freud, padre del psicoanálisis, que tanto contribuyeron a los descubrimientos de la conducta humana, también hizo que contribuyó a la investigación de la investigación de la evolución humana. El objetivo principal de este trabajo e identificar los factores que contribuyeron a la evolución de la especie humana, en particular, el comportamiento de las tribus humanas primitivas que vivieron en África, que se representa en la obra Totem y tabú por Sigmund Freud. Freud vivió al mismo tiempo que la comunidad científica estaba descubriendo su origen, su historia como especie y el desarrollo de las teorías de la evolución y fue uno de los primeros en estar de acuerdo con las hipótesis de Charles Robert Darwin, mientras que la mayoría de los estudiosos de la achincalhava- tiempo la. Freud describió el comportamiento de las primeras tribus humanas que muy probablemente contribuyeron a evitar la extinción del Homo sapiens, esos comportamientos todavía rigen las costumbres y los valores de nuestra sociedad, y por lo tanto seguirá colaborando para controlar el flujo de alelos letales en la especie humana.

Keywords: evolición de la especie humana. Freud y biología. evolución. variabilidad genética.

\footnotetext{
${ }^{1}$ Alelos letais são genes que podem levar à morte o portador, seja antes mesmo de nascer, ou durante a infância, adolescência ou fase adulta do indivíduo. Estes genes foram descobertos em 1904 pelo geneticista francês Cuénot.
} 


\section{A ORIGEM DA VIDA}

Desde o inicio dos tempos, quando os primeiros humanos começaram a ser comunicar pela linguagem oral, surgiram muitas perguntas intrigantes a respeito sua própria História: Como o planeta Terra foi formado? Como surgiu vida na Terra? De onde veio à espécie humana? A Terra acabará um dia? Como? Muitos estudiosos, filósofos e religiosos tentaram explicar a origem do universo, dos animais e das plantas, ou seja, do planeta Terra.

[...] as pessoas buscaram por muito tempo as causas dos fenômenos em prédeterminações: a vontade de Deus ou as causas aristotélicas (os propósitos pelas quais os eventos ocorreram) ao invés das causas efetuadoras (os mecanismo que fazem com que os eventos ocorram) (FUTUYMA, 1942, p. 2).

Para responder a essas indagações surgiram muitas teorias, as mais famosas são: Criacionismo, Fixismo, Lamarckismo, Darwinismo e Neodarwinismo.

\section{AS ANTIGAS TEORIAS SOBRE A ORIGEM DA VIDA}

Várias são as teorias que explicam a origem da vida, a mais conhecida e aceita até hoje, é o Criacionismo, apregoado pela igreja Católica, consiste na teoria de que todos os seres vivos, o ambiente e tudo que há foram criados por um Criador, um ser supremo e poderoso. Todos os animais e plantas estão do mesmo modo como ele fez não se modificam ao longo do tempo.

A teologia cristã adotou uma interpretação quase literal da Bíblia, incluindo a criação especial (a criação direta de todas as coisas efetivamente em sua forma atual) [...]. As essências eternas, imutáveis, de todas as coisas existem na mente de Deus, mas seria uma imperfeição divina negar a existência material a algo que ele concebeu. Uma vez que Deus é perfeito, Ele deve ter materializado tudo que existia como sua ideia. Todas as coisas devem ter sido criadas no começo, e nada que Deus considerou apropriado criar poderia se extinguir, porque negar a existência de qualquer coisa em qualquer tempo introduziria imperfeição em sua criação. Uma vez que a ordem é claramente superior à desordem, as criações de Deus devem se adequar a um padrão: A Scala Naturae, ou grande Escala dos seres vivos. Esta "escada de Vida", percebida na gradação entre a matéria inanimada 
passando pelas plantas, animais "inferiores" e humanos, até os anjos e outros seres espirituais, deve ser perfeito e não apresentar lacunas; ela deve ser permanente e imutável, e todo o ser deve ter seu lugar fixado de acordo com o plano de Deus. Uma vez que esta ordem natural foi criada por um Deus perfeito, que é natural é bom e deve ser o melhor dos mundos possíveis. Esta hierarquia natural se estendeu às classes sociais altas e baixas nas sociedades humanas (FUTUYMA, 1942, p. 3).

A curiosidade de muitos humanos não permite aceitar essa História, descrita anteriormente por Futuyma (1942). Para os estudiosos, filósofos e para a Ciência, um fato é considerado como verdadeiro quando pode ser comprovado. Se "Deus criou tudo que há e nada poderia se extinguir", para onde foram os Dinossauros? Então, eles não existiram? Mas, de onde vieram todos aqueles ossos gigantes? Dentre as ideias do Criacionismo, inclui-se a teoria que a Terra era plana, que era perigoso andar para além das montanhas e do horizonte, pois se corria o risco de cair em buraco negro sem fim, entre outras fantasias, as quais foram sendo desmistificadas com anos de estudo e de observação. As grandes navegações provaram que a Terra não era plana como se pensava.

O Fixismo, apregoado pelos fixistas, cujo representante mais famoso é Aristóteles, acreditavam que as espécies eram fixas, imutáveis, e que "nenhum ser vivo 'vem' de qualquer outro", ou seja, não acreditavam na evolução das espécies. Para eles, cada característica de um ser vivo é advinda da Criação, para exercer uma função específica (MEYER, 2005, p.17).

A Igreja foi perdendo o poder de persuasão sobre as pessoas, por vários motivos, dentre eles, a ascensão de alguns estudiosos que discordavam dela, como por exemplo, Galilei Galileu, juntamente com Copérnico que provaram a teoria do Heliocêntrismo - o Sol estar no centro do Universo, opondo-se ao que a igreja dizia: a Terra estava no centro do universo (Geocêntrismo). Ainda hoje existe uma polêmica discussão a respeito do surgimento da vida. Há muitos cientistas, filósofos e estudiosos que usam a existência de Deus para explicar fenômenos que eles não sabem explicar como acontece, ou como surgiu. Assim o fez Descartes (1637), no Discurso do Método, e muitos biólogos que se dizem evolucionistas também o fazem. 
E, com o declínio de alguns pensadores como Aristóteles e os "escolásticos", que, segundo Bacon (1626), elaboravam teorias para reforçar o que a Igreja dizia, as pessoas começaram a desacreditar na teoria Criacionista (principalmente os abastados) e pensar na possibilidade da existência da evolução.

A teoria da evolução biológica é a expressão amadurecida de duas correntes revolucionárias de pensamento antitético a uma visão de mundo que prevaleceu por muito tempo. Em primeiro lugar, o conceito de um universo em constante mudança foi substituindo a visão, até então não questionada, de um mundo estático, idêntico em sua essência à criação perfeita do criador (FUTUYMA, 1942, p.2).

De acordo com Meyer (2005), a teoria da evolução biológica propõe, portanto, que os seres vivos não são imutáveis: os que são vistos hoje nem sempre existiram; são resultados da evolução de seus ancestrais e não permanecerão assim, estão em constante evolução.

Segundo Futuyma (1942), o primeiro a defender as ideias evolucionistas foi Jean-Baptiste Pierre Antonie de Monet, cavaleiro de Lamarck (1744-1829). No entanto, ele não afirmou que os seres vivos eram descendentes de ancestrais, ele admitiu o surgimento de alguns seres vivos por geração espontânea, e a partir de então eles teriam progredido inevitavelmente rumo à complexidade e perfeição, iniciando a evolução. E atribuiu a Deus o surgimento espontâneo desses primeiros seres vivos.

Lamarck sustentou que o caminho particular da progressão é guiado pelo ambiente, e que o organismo responde mudando seu comportamento e, consequentemente, usando alguns órgãos mais que os outros. Em outras palavras, uso e desuso alteram a morfologia, que é transmitida para as gerações subsequentes. Essa teoria claramente se aplica mais aos animais que às plantas (FUTUYMA, 1942, p. 4).

Essas ideias de Lamarck provocaram polêmica, ele foi alvo de críticas e chacotas, ao aplicá-las nos mais diversos exemplos, era óbvia a ineficácia. Por exemplo, Como um organismo, 'manda' em seu próprio corpo? Exemplo, um grilo vive na grama verde e seu corpo é verde, a grama morre, fica 
amarela, o grilo conseguiria 'mandar' no seu próprio corpo para ficar amarelo? Como ele faria isso?

Se quanto mais usarmos um órgão melhor ele fica, então, aos 90 anos deveríamos ter visão infravermelha, ou olhar para a pele e ver o interior das células epiteliais, ao contrário, quanto mais idoso é o ser humano, menos ele enxerga.

Ao dizer que todas as novas características adquiridas são transmitidas aos descendentes, Lamarck deu "outro tiro no pé". Suponhamos um homem perfeito fisicamente, e que num dado momento, perdeu a perna em um acidente, ficou com uma perna só; de acordo com essa teoria de Lamarck, se ele tivesse um filho(a) essa criança nasceria com uma só perna, assim como seu pai. De fato, as ideias de Lamarck deixaram muitas falhas, por conseguinte, não foram aceitas.

É sabido que nem todo processo evolutivo conduziu os seres vivos a condições favoráveis na natureza, há seres vivos que a evolução os colocou em situações insatisfatórias, como por exemplo, as lombrigas - Ascaris lumbricoides, que não possuem sistema digestivo, consequente, são parasitas obrigatórias, e dependem de outros seres vivos (hospedeiros) para completar seu ciclo evolutivo e obter seu habitat. Caso os hospedeiros 'aprendam' a evitá-la, ela poderá ser extinta. Todavia, não se pode negar que Lamarck contribuiu para os estudos evolutivos, como propõe Futuyma:

\footnotetext{
Lamarck merece respeito como o primeiro cientista que destemidamente advogou evolução e tentou apresentar um mecanismo para explicá-la. Suas ideias foram rejeitadas quase universalmente, não porque ele abraçava a herança das características adquiridas, mas porque os principais naturalistas de então não reconheciam evidencias de evolução (FUTUYMA, 1942, p. 4).
}

De fato, Lamarck conquistou seu espaço, e sempre que se fala em evolução, suas ideias são lembradas; nem que seja pra evidenciar o erro, mas é lembrado. Entretanto, o mérito de o "Pai da Evolução" é atribuído a Charles Robert Darwin (1809-1882).

Darwin "mais do que ninguém estendeu aos seres vivos e a própria espécie humana a conclusão de que a mutabilidade, não a estase, é a ordem natural". Ele inseriu todos os seres vivos em sua 
teoria evolucionista, e encontrou provas muito convincentes para sustentar suas ideias. Muitos foram os estudiosos que aceitaram e reforçaram as teorias de Darwin, dentre eles Alfred Russel Wallace e Sigmund Freud.

Darwin tornou supérfluas as explicações teológicas ou espirituais dos processos vitais. Juntamente com a teoria materialística da história e sociedade de Marx e a atribuição do comportamento humano às influências sobre as quais temos pouco controle, feita por Freud, a teoria da evolução de Darwin foi um elemento crucial na plataforma do mecanicismo e materialismo - em grande parte da ciência - a qual tem sido, desde então, o palco da maior parte do pensamento ocidental (FUTUYMA, 1942, p. 2).

Charles R. Darwin inicialmente não aceitava as ideias evolucionistas, até que, em dezembro de 1831, embarcou no navio H.M.S. Beagle, onde ficou 4 anos e 10 meses velejando por diversos lugares do mundo. Quando chegou à Ilha Galápagos, o ornitólogo Jhon Gould indicou-Ihe "que seus espécimes de tordos-dos-remédios (e não tentilhões) das ilhas Galápagos eram tão distintos de uma ilha para a outra que chegava a representar espécies diferentes" (FUTUYMA, 1942, p. 5). Segundo Futuyma (1942), a distinção entre os pássaros existente nas ilhas de Galápagos que de tão diferentes nem parecia ser da mesma espécie fez Darwin duvidar da imutabilidade das espécies. A partir de 1836, ele preocupou-se em reunir evidências da evolução e mecanismos que pudessem explicá-la.

Em 1838, ao ler o ensaio de Malthus sobre população, consente com seu amigo que a população cresce de forma exponencial e que os recursos da Terra (alimentos) não acompanham esse crescimento. A partir daí, começa a estudar sobre esses problemas, até que 20 anos depois publica A origem das espécies por meio da Seleção Natural, ou a Preservação das Raças Favorecidas na luta pela Vida (FUTUYMA,1942, p.23). No livro, o ambiente assume papel central para explicar a evolução. Ademais, afirmou-se que

A luta pela sobrevivência resulta inevitavelmente da rapidez com que os seres organizados tendem a multiplicar-se. Todo o indivíduo que, durante o estado natural da vida, produz muitos ovos ou muitas sementes, deve ser destruído em qualquer período da sua existência, ou durante uma estação qualquer, porque, de 
outro modo, dando-se o princípio do aumento geométrico, o número de seus descendentes tornar-se-ia tão notável, que nenhuma região os poderia alimentar. Também, como nascem mais indivíduos que os que conseguem sobre viver, deve existir, em cada caso, luta pela sobrevivência, quer com outro indivíduos de espécies diferentes, quer com as condições naturais da vida. É a doutrina de Malthus aplicada com a mais considerável intensidade a todo o reino animal e vegetal, porque não há nem produção artificial de alimentação, nem restrição ao acasalamento por prudência. Embora algumas espécies se multipliquem hoje mais ou menos rapidamente, não pode suceder o mesmo para todas, porque a terra não as comportaria (DARWIN, 1859, p. 70).

Ao constatar que a população crescia rápido de mais e se a natureza não colocasse empecilhos para conter esse crescimento, não haveria espaço e alimento para todos, Darwin percebeu que a teoria de Wallace sobre a Seleção Natural de fato acontecia. A natureza oferecia a todos os seres vivos intempéries (falta de água, comida, habitat, predadores, mudanças climáticas, doenças etc.) e aqueles que tivessem as melhores características físicas e biológicas, as suportariam, sobreviveriam e, ao acasalarem, perpetuariam sua espécie transferindo suas características biológicas a seus descendentes - hereditariedade; enquanto os que não resistissem morreriam. Para Darwin (1859), em uma população, os indivíduos de uma mesma espécie são semelhantes, mas não são iguais entre si. Existem pequenas variações (um mais altos, outros mais baixos, magros, gordos, fracos, fortes, feios, extravagantes, etc.) que podem dar vantagens e desvantagens aos indivíduos, dependendo das condições ambientais. Esse fato, juntamente com a seleção natural, que "seleciona" os mais adaptados para uma dada região, é o que provoca o processo evolutivo.

Vejamos um exemplo, bem simplório, mas, que explica como a seleção natural acontece: Pense em um cardume de sardinhas, há peixes grandes e outros pequenos, ambos da mesma espécie. Um pescador que utiliza uma rede com malhas grandes "seleciona" os peixes maiores. Estes, com o tempo, desaparecem da natureza. Já os pequenos, que não foram predados, ficam no ambiente e deixam descendentes com as suas características. Após um tempo, se essa pesca predatória continuar a acontecendo, haverá uma modificação no perfil dessas sardinhas, que serão todas de porte pequeno. No fenômeno anterior, o fator que agiu como "seleção natural" foi o pescador. Ele selecionou quais sardinhas tinha as melhores características. Nesse exemplo, as sardinhas 
pequenas forma privilegiadas, mas, num outro exemplo, elas poderiam ter sido prejudicadas. E se as sardinhas fossem selecionadas por um colecionador de peixes de aquário? Ele certamente daria preferência aos peixes pequenos. Ou seja, o mesmo indivíduo pode ter características favoráveis ou desfavoráveis, o que dependerá das circunstâncias e do ambiente.

Quanto à origem das espécies, Darwin não a considerou como um processo linear, mas como processo de divergência a partir de ancestrais comuns. Para ele, "duas espécies semelhantes seriam descendentes de uma única espécie que teria existido no passado. Desde sua origem a partir desse ancestral comum, elas teriam divergido dando origem a diferenças que vemos". Todas as espécies (tanto vegetais, quanto animais) eram aparentadas umas com as outras (MEYER, 2005, p.25). O livro A origem das espécies e a seleção natural foi o "divisor de águas" nas teorias evolucionistas. Muitos aceitaram; outros aproveitaram para escarnecer Darwin, dizendo que ele afirmara que viemos do macaco. Até caricatura de Darwin no corpo de macaco rolou pela cidade de Londres. Para o Ego elevado de muitos humanos, é difícil aceitar ser comparado a outros animais que denominam irracionais. Darwin nunca disse que viemos dos macacos, e, sim, que tínhamos um ancestral comum, que teria existido milhões de anos atrás. Ele explicou essa proximidade da seguinte maneira:

Chimpanzés e humanos são, ambos, resultados de transformação evolutiva. Eles partilham um ancestral comum, que existiu há algum tempo, e sofreram mudanças desde que essa espécie ancestral se ramificou pela primeira vez. Nós não descendemos dos chimpanzés, nem chimpanzés descendem de nós; somos espécies distintas que se originaram de uma outra, que existiu no passado, [...] Quando dizemos que "viemos dos macaco", queremos dizer que somos descendentes de um animal que provavelmente tinha muitos traços semelhantes aos dos macacos atuais, mas, ao mesmo tempo, não era um macaco idêntico ao que vemos hoje (MEYER, 2005, p. 25-26).

Darwin "quebrou" o pedestal que os humanos criaram para si, como seres superiores. Segundo ele, homens, macacos e todos os animais descendem de um ancestral comum. O Homem, que sempre se colocou como dono do mundo, acostumado a extrair da natureza tudo que for necessário para sua sobrevivência, luxo e conforto, viu-se ameaçado pelas "forças naturais", sobre 
as quais ele não tem muito controle. Em resposta a essa "ameaça", muitos denegriram veementemente a imagem do evolucionista britânico.

Em respostas as críticas e para comprovar suas teorias, o "Pai da evolução" começou a atentar-se para semelhanças e diferenças entre os seres vivos, encontrando informações importantes, que utilizou para provar a existência da evolução. Este artigo exemplificará apenas os órgãos homólogos e os vestigiais. Na comparação da estrutura óssea e morfologia dos seres vivos, Darwin observou que ossos das "patas de animais aquáticos, e as asas de morcegos são na essência os mesmos. As estruturas, no entanto, diferem, uma vez que, os ossos que as compõem têm tamanhos diferentes". Esses são denominados de órgãos homólogos ${ }^{2}$ (MEYER, 2005, p. 28). A figura a seguir, ilustra bem a homologia existente entre os ossos de um braço humano, da pata de um cavalo, da asa de um morcego e da uma nadadeira de baleia.

Figura 1. Evidências morfológicas.

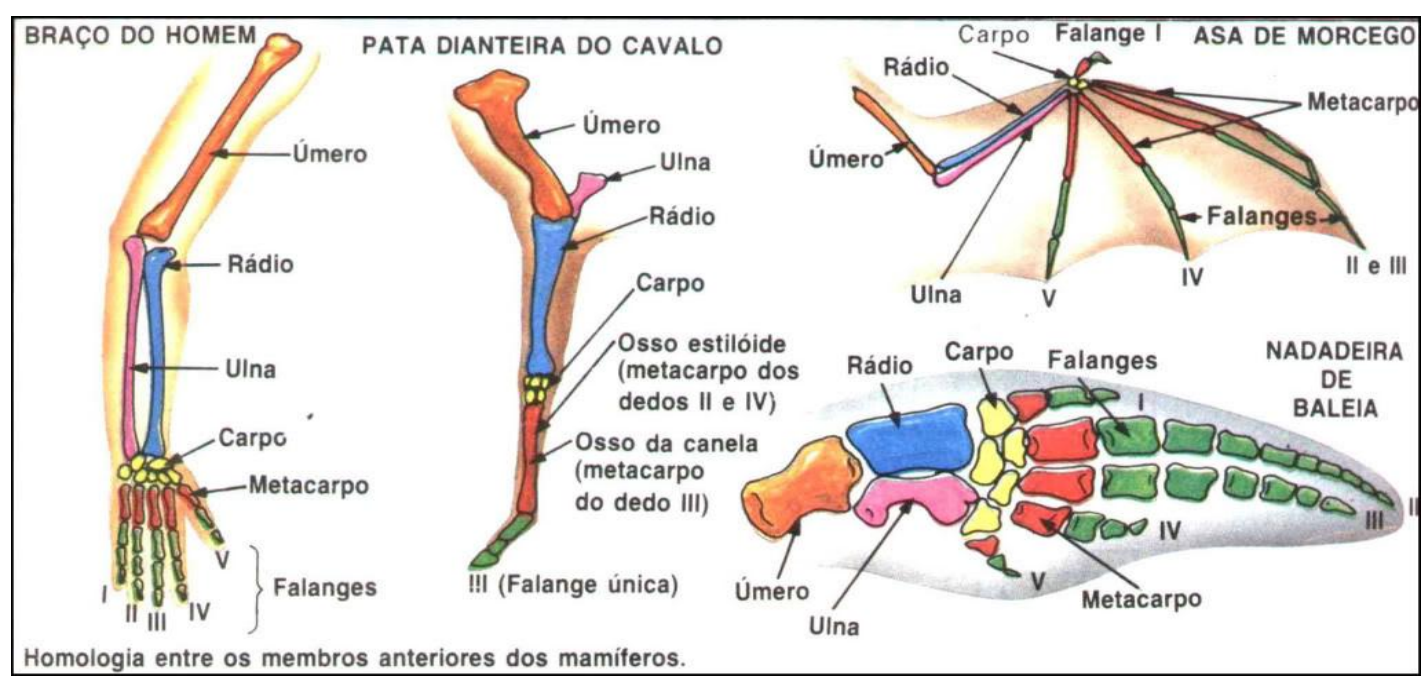

Fonte: Rodrigues, 2010.

Ao observar a estrutura dos ossos, conclui-se que de fato, todos os membros são constituídos pelos mesmos ossos. Por exemplo, o Rádio. As epífises (extremidades) desse osso nos diferentes animais são muito semelhantes, e a diferença está no comprimento e na espessura. Isso está de acordo com o porte físico e a maneira como o animal a utiliza. Dessa forma, ossos de atuais

\footnotetext{
${ }^{2}$ Órgãos homólogos são órgãos que têm origem embrionária semelhante, porém podem ou não desempenhar as mesmas funções. Isso nos leva a crer que diferentes seres vivos tiveram um ancestral comum, que, conforme evoluía, originou novas espécies, desenvolvendo e adaptando os órgãos de acordo com suas necessidades. Por exemplo: braço humano, asas de morcego, nadadeiras anteriores de um golfinho.
} 
animais e fósseis foram utilizados por Darwin para comprovar a semelhança e a 'descendência' entre os seres vivos.

Outra prova irrefutável são os órgãos vestigiais. Segundo Meyer (2005), órgãos vestigiais são estruturas aparentemente sem função, mas semelhantes a órgãos funcionais em outros seres vivos. Existem vários exemplos, como por exemplos, os vestígios de apêndices que se encontra nas cobras, em outros répteis eles originam patas. No ser humano há o osso cóccix que é invertido para dentro das nádegas, em outros mamíferos, esse osso é extrovertido e origina o rabo.

De acordo com Meyer (2005), após comprovar suas ideias, Darwin elaborou as cinco "teorias darwinistas da evolução" estas são:

I- Todos os seres vivos são em algum grau aparentados entre si;

II- Novas espécies surgem de espécies preexistentes;

III- Variações que existem dentro de uma espécie dão origem às diferenças entre espécies;

IV-Os processos que levam à diferenciação de populações e aqueles que explicam as diferenças entre espécies é a suposição de que a evolução é gradual;

$V$ - De uma geração para outra, a população se transformará: as características que mais favorecem os indivíduos passam a seus descendentes com mais frequência que as desfavoráveis e, com o tempo, a população acumulará muitas características vantajosas. Em suma, Charles R. Darwin, com suas ideias, comprovações e teorias, iniciou a marcha da Ciência, rumo a teoria da Biogênese ${ }^{3}$. Contudo, havia alguns fatos que as proposições de Darwin não explicavam. Um exemplo: como explicar o surgimento de uma característica diferente em um indivíduo, que não aparece nos demais, membros da população? De onde veio o primeiro ser vivo? Para essas incógnitas as teorias de Darwin não tinham explicação. Somente com as pesquisas de Mendel, podem-se completar as lacunas nas teorias de Darwin e formular o Neodarwinismo.

\footnotetext{
${ }^{3}$ Biogênese é a teoria de que todos os seres vivos são originados a partir de outro ser vivo.
} 


\section{A 1a LEI DE MENDEL E A TEORIA SINTÉTICA DA EVOLUÇÃO}

No século XX, em 1900 iniciam-se os estudos de Genética ${ }^{4}$, que desvendará a existência do DNA ${ }^{5}$ e como acontece a transmissão das características humanas. Exatamente 41 anos após a publicação do livro A origem das espécies e a seleção natural, Gregor Mendel (1822 - 1884), um monge que desenvolveu várias pesquisas com ervilhas, inicia os estudos genéticos e com isso, descobriu como funciona a hereditariedade.

Uma terceira alternativa à seleção natural, e talvez a mais influente, Foi o mutacionismo, [...] nasceu do sucesso da genética experimental, que desde o início do século havia demonstrado a ocorrência de mutações - súbitas alterações herdáveis - em seres vivos, trabalhos em laboratório haviam demonstrado, sem sombra de dúvida, que mutações ocorriam e logo ficou claro que essas alterações também ocorriam na natureza. Os argumentos que sustentavam a mudança evolutiva por seleção natural pareciam comparativamente pouco sólidos, diante do rigor com que havia sido demonstrada a ocorrência de mutações (MEYER, 2005, p.47).

Eis a resposta! As características que "apareciam” em um indivíduo e não estava presente nos demais da população era a mutação ${ }^{6}$. Quanto à hereditariedade, Mendel, enunciou inicialmente uma teoria, hoje conhecida como a 1a lei de Mendel: "cada caráter é condicionado por um par de fatores que se separam na formação dos gametas, nos quais ocorrem em dose simples" (LINHARES, 2013, p.16).

\footnotetext{
${ }^{4}$ Genética é a área da Ciência, mais especificamente da Biologia, que investiga a constituição dos genes, como se processa a hereditariedade, de que forma os atributos orgânicos são passados de uma geração para a outra, que distúrbios físicos podem estar presentes no mapa genético do organismo de cada um. Ela também estuda a forma como se dá a transmissão química de dados contidos nos genes, de pais para filhos, ao longo do tempo.

${ }^{5}$ DNA é a sigla de ácido desoxirribonucleico, ou ADN. O DNA juntamente com o RNA, formam os ácidos nucleicos, localizados no interior do núcleo celular. O DNA e RNA são formados por nucleotídeos. Em 1944, os cientistas norteamericanos Avery, Macleod e Macrty, comprovaram que os genes são feitos de DNA. Dessa forma, o material genético humano é constituído quimicamente por nucleotídeos, que formam os genes; todos os genes juntos compõem o DNA, que se fragmenta formando os cromossomos que, na espécie humana, contam 46.

${ }^{6}$ Mutação é o termo empregado para uma modificação brusca no material genético, acontece ao acaso, e pode ser transmitida aos descendentes. Ela pode ocorrer em uma parte do material genético, modificando a molécula de DNA e a alterando a proteína a ser produzida, ou pode ser mais grave e alterar o cromossomo deformando-o, ou aumentando ou diminuindo o número de cromossomos, no indivíduo.
} 
Nessa 1a lei, Mendel, explicita que cada característica é produzida a partir da interação de um par de "fatores" (genes ${ }^{7}$ ), cada "fator" herdado de um genitor (um vem do pai e outro da mãe), estão, portanto, em "dose" dupla em cada indivíduo. Na hora da "formação dos gametas" (espermatozoide ou óvulo), eles se separam de forma aleatória, para que, no momento da fecundação (fusão do espermatozoide no óvulo), eles possam unir-se novamente e originar a determinada característica no descendente.

Com as teorias de Mendel (1 $\underline{1}^{a}$ e $2^{a}$ lei), as diversas características vegetais e animais foram explicadas. Em sua primeira lei, ele esclarece que os seres vivos, no interior do corpo, tinham "fatores" que determinavam os caracteres. Um era "fator dominante" (gene dominante ${ }^{8}$ ), ao qual domina o outro "fator", não o deixa manifestar-se. E o outro era "fator recessivo" (gene recessivo ${ }^{9}$ ) que para originar a característica necessita estar em dose dupla (LINHARES, 2013, p.16).

Em sua segunda lei, Mendel evidencia que muitas características de um indivíduo não são formadas apenas por um par de "fatores", mais sim por dois ou até mais pares. Linhares elucida-a:

Essa é a segunda lei de Mendel, também chamada lei da recombinação ou lei da segregação independente, e pode ser assim enunciada: "Em um cruzamento em que estejam envolvidos dois ou mais caracteres, os fatores que determinam cada um se separam (se segregam) de forma independente durante a formação dos gametas, se recombinam ao acaso e formam todas as combinações possíveis (LINHARES, 2013, p.16).

Com a 2 a lei de Mendel, desvendou-se como aconteciam características tanto em plantas quanto em animais, isto é, como se dava a cor de pele nos humanos, a pelagem de muitos animais, a cor dos olhos humanos, e vários outros exemplos. Com isso, abriu a porta dos estudos para as

\footnotetext{
${ }^{7}$ Gene ou alelo (gen em alemão) termo utilizado pela primeira vez pelo botânico Wilhelm Johannsen, que até nos tempos de hoje significa a "unidade fundamental de transmissão hereditária". Um gene corresponde a uma sequência de DNA responsável pela produção de uma proteína. Cada gene se localiza em um certo ponto do cromossomo (o seu lócus).

${ }^{8}$ Gene dominante ou alelo dominante, é o gene que mesmo estando presente em dose simples (um só), é capaz de determinar o fenótipo (característica).

${ }^{9}$ Gene recessivo ou alelo recessivo precisa estar em dose dupla, ou seja, ter dois deles (cada um herdado de um genitor) para que o fenótipo (característica) se expresse.
} 
interações entre os genes e a variedade deles. Vale ressaltar que, à época de Mendel, os termos técnicos de genéticos ainda não haviam sido criados. Portanto, o termo "fatores" significa gene ou alelo.

A disseminação destas pesquisas mendelianas resultou numa significativa depreciação do darwinismo. Foi em 1920 que esta teoria ressurgiu, unindo-se as ideias de Mendel e formando a "teoria evolutiva mais influente do século XX, a teoria sintética da evolução" ou Neodarwinismo que surgiu a partir de 1930 (MEYER, 2005, p.48).

Três pesquisadores tiveram papel destacado na história inicial dessa área: Ronald Aylmer Fischer (1890-1962) e Jhon B. S. Haldane nos E.U.A. Ao longo da década de 1920, Fisher aplicou uma série de técnicas matemáticas que havia desenvolvido ao estudo dos efeitos da seleção sobre as populações apresentando variações genéticas. Ele construiu modelos matemáticos que descreviam como a frequência de genes mudava sob o efeito da ação da seleção natural e demonstrou que a genética mendeliana permitia a compreensão de como diferenças sutis entre indivíduos seriam geradas e transmitidas para as gerações seguintes, podendo acumular-se por seleção natural. Haldane apresentou exemplos concretos que demonstravam que a seleção natural poderia ter efeitos muito mais rápidos sobre as populações do que pensava Sewall Wright, que, por sua vez, considerou o papel das interações gênicas como fonte adicional de variabilidade em pequenas populações com elevadas taxas de cruzamento entre parentes e fez, ainda, importantes contribuições ao estudo da subdivisão das populações e da herança de características quantitativas (MEYER, 2005, p. 48-49).

Os cálculos matemáticos de Fisher fizeram a teoria comprovar-se como ciência. Com a ação da seleção natural e a teoria de Mendel sobre mutação, foi possível explicar mudanças bruscas que ocorreram nas populações em curto prazo de tempo.

Com o Neodarwinismo encontraram-se respostas para os fósseis intermediários que Darwin não achou (ele buscou por fósseis que provavelmente existiram entre um animal atual e seu ancestral mais antigo) para demonstrar o processo evolutivo. Na verdade esses animais nunca existiram. 
Pois, o fator que modificava a espécie em curto prazo de tempo era a mutação, ao qual, a nova característica adquirida era transmitida para as próximas gerações.

As interações gênicas ${ }^{10}$ favoreceram a variabilidade genética ${ }^{11}$ numa população pequena de organismo. Assim, as primeiras tribos humanas conseguiram se diferenciar, mesmo sendo pequenas, pois a interação entre os genes produziram características diferentes nesses indivíduos, e sobreviveram aqueles que nasceram com genes favoráveis à vida no ambiente em que viviam. Dessa forma, a variabilidade genética, favoreceu a diversidade genética ${ }^{12}$.

O Neodarwinismo explica de maneira satisfatória o surgimento de novas características e analisa os fatores que alteram a frequência gênica das populações, como a mutação, a seleção natural, as migrações, isolamento geográfico/reprodutivo, e ainda a deriva genética, ou seja, estuda a dinâmica das populações (SILVA JÚNIOR, 2013, p. 203).

\footnotetext{
10 Interações gênicas denominação que se dá a interações, combinações, entre pares diferentes de genes para determinar uma característica no ser vivo. Por exemplo, a cor da pele humana é determinada pela interação de dois pares de genes AABB (pele preta) e aabb (pele branca), sendo assim, um cruzamento de um casal heterozigoto (com genes diferente) $\mathrm{AaBb} \times \mathrm{AaBb}$ tem-se 16 fenótipos (características) possíveis: $\mathrm{AABB}, \mathrm{AABb}, \mathrm{AaBB}, \mathrm{AaBb}, \mathrm{AaBB}, \mathrm{AaBb}$, $a a B B, a a B b, A a B b, A a b b, a a B B$, aabb, AABB, AAbb, AaBb, Aabb. Portanto 2 pares de genes pode resultar em muitas características, é por isso que existe várias cores de pele, sem contar a interação que fazem com a luz do sol.

${ }^{11}$ Variabilidade genética são as diferenças genéticas que existem numa dada população, os genes que determinam um característica pode ter várias versões (alelos), a maneira aleatória que esses genes se unem (variabilidade gênica) garantem que a população não se extingue, caso ocorra catástrofes ou propagação de doenças, já que indivíduos com certos alelos ou combinações de alelos podem ter precisamente as características necessárias para sobreviverem e se reproduzirem sob novas condições.

12 Diversidade genética é a variedade de alelos e genótipos presentes no grupo sob estudo (populações, espécies ou grupos de espécies). A diversidade genética é o material bruto sobre a qual a seleção natural atua para permitir a adaptação e a evolução dos organismos e a sua adequação às mudanças ambientais. A perda da diversidade genética reduz o potencial evolutivo e está também associado com a redução do sucesso reprodutivo.
} 


\section{A SELEÇÃO NATURAL AMEAÇA TAMBÉM A ESPÉCIE HUMANA: GENES LETAIS}

A teoria da variabilidade gênica explica favoravelmente como os primeiros humanos conseguiram sobreviver. No entanto, a variabilidade não evita a ação da seleção natural sobre a espécie humana. Foi o que constatou o médico inglês Garrod:

[...] Archibald Garrod (1857-1936), um médico inglês, descreveu a alcaptunúria. Esta é uma doença rara, provoacada por um alelo recessivo de um gene autossômico, codifica uma enzima ligada ao metabolismo dos aminoácidos fenilalanina e a tirosina. Garrod desenvolveu a ideia de que muitas doenças humanas seriam provocadas por aquilo que ele chamou de erros inatos do metabolismo, ou seja, defeitos metabólicos transmitidos geneticamente. [...] Certas doenças deviam-se a alterações em determinadas vias metabólicas, como resultado da não produção de certas enzimas, ou da produção de uma versão defeituosa da enzima (SILVA JÚNIOR, 2013, p. 83).

Nas palavras de Silva Júnior (2013), percebe-se que, se por um lado a variabilidade genética favoreceu o crescimento da população humana, também foi agente da seleção natural sobre a espécie humana, pois nos genótipos ${ }^{13}$ humano há genes que podem causar prejuízos a espécie, como doenças graves e até a morte - os genes letais ${ }^{14}$. Esses genes desfavoráveis na espécie humana podem provocar, além da alcaptunúria, anomalias como anemia falciforme, fenilcetonúria, hipotireoidismo congênito, fibrose cística ou albinismo, entre outras, esclarece Silva Júnior (2013). Os genes letais que estão presentes no DNA ${ }^{3}$ humano, em uma frequência baixa, são genes recessivos ${ }^{6}$. No entanto, quando acontece o coito entre um casal que tem um gene recessivo comum, a possibilidade de a doença ressurgir e comprometer a vida desse descendente aumenta consideravelmente.

[...] a frequência de um alelo recessivo pode ser estimada como a raiz quadrada dessa frequência. Por exemplo, a frequência do nanismo associado à distrofia de cartilagem dos ossos longos no condor da Califórnia, uma espécie em perigo de extinção, é 0,03 , então o alelo recessivo que causa esta condição tem uma frequência estimada de $v 0,03=0,17$. Esta é uma frequência surpreendentemente

\footnotetext{
${ }^{13}$ Genótipo é a constituição gênica de um indivíduo, ou seja, o par de alelos (genes) que ele possui para uma determinada característica. Mas também pode significar a quantidade total de genes (todo o DNA) do indivíduo.
} 
alta para um alelo recessivo letal, mas não é incomum em outras populações derivadas de muito poucos indivíduos fundadores, incluindo populações de outras espécies em perigo (FRANKHAM, 2008, P 19-20).

Como exposto por Frankham (2008), esses genes letais, em uma população pequena que cruza entre si, podem ter uma frequência "surpreendentemente" alta. Se atualmente eles estão "controlados", isso significa que houve uma redução deles na população humana. Mas o que ocorreu para que isso acontecesse? Como os humanos controlaram o surgimento desses alelos recessivos e letais?

\section{A estratégia de CONTROLE DE endOgAMIA UTILIZADA PELO Homo sapiens NOS PRIMÓRDIOS DA CIVILIZAÇÃO}

Segundo Futuyma (1942), devido a implicações sociais, a Genética e a Evolução humana são assuntos repletos de emoções e a literatura nessa área de conhecimento é impregnada por afirmativas baseadas em evidências e suposições muitas vezes não comprovadas. Aquele que escreve uma história evolutiva mistura suas conviçcões e seu modo de interpretar os fatos para reconhecer a veracidade, por isso se faz necessário comparar a narrativa com outros autores buscando semelhanças entre eles, para desenvolver uma noção de como os fatos históricos aconteceram. A História da Evolução humana já foi manipulada para atender o preconceito e interesse de muitos cientistas gananciosos e escravocratas, que diziam e "provavam" que a raça branca era superior à raça negra, enquanto seu objetivo era convencer sociedade de que os negros, por serem "naturalmente inferiores", poderiam ser explorados e executar as mais diversas funções laborais atendendo os desejos e caprichos dos brancos.

Todavia, a obra de Sigmund Freud intitulada Totem e Tabu, de 1914, relata histórias provavelmente reais sobre o hábito e costumes das primeiras tribos humanas na Terra e demonstra evidências de como aconteceu a variabilidade genética na espécie humana. Trata-se de uma obra de antropológica social destinada a investigar o comportamento humano em relação ao "totem" (sagrado) e o "tabu" (temido), que Freud pesquisou para explicar os comportamentos humanos de sua época. Entretanto, de formar indireta, Sigmund contribuiu para a Biologia Evolucionista ao

\footnotetext{
${ }^{14}$ Há literatura que também os chama de alelos letais ou genes homozigotos recessivos deletérios.
} 
explicar como a endogamia ${ }^{15}$ foi evitada na espécie humana. As primeiras tribos humanas não conheciam a Biologia evolucionista, muito menos a Genética da Conservação, mas desenvolveram mecanismos (é indiferente se consciente ou inconscientemente) para evitar o ressurgimento dos genes letais. Eles evitaram o acasalamento entre consanguíneos, e entre parentes muito próximos como explicitado pelo estudioso:

Tanto por razões externas como internas, escolherei como base dessa comparação as tribos que foram descritas pelos antropólogos como sendo dos selvagens mais atrasados e miseráveis, os aborígenes da Austrália, o continente mais jovem, em cuja fauna também podemos ainda observar muita coisa que é arcaica e já pereceu em outras regiões. Os aborígenes australianos são considerados uma raça distinta, sem apresentar relação física nem linguística com seus vizinhos mais próximos, os povos melanésios, polinésio o e malaio. Estes não constroem casas, nem abrigos permanentes; não cultivam o solo, não criam animais domésticos, a exceção do cão; não conhecem nem mesmo a arte da cerâmica. Vivem inteiramente da carne dos animais que caçam e das raízes que arrancam. Reis e chefes são desconhecidos entre eles; os assustados comuns são decididos por um conselho de anciães. É altamente duvidoso que lhes possa atribuir qualquer religião moldada na adoração de seres superiores. As tribos do interior do continente, que têm de lutar contra condições de existência mais árduas em virtudes da escassez de água, parecem ser, sob todos os aspectos, mais primitivas que as vivem perto da Costa. Naturalmente não era de se esperar que a vida sexual desses canibais pobres e desnudos fosse moral no nosso sentido ou que seus instintos sexuais estivessem sujeitos a um elevado grau de qualquer restrição. Entretanto verificamos que eles estabelecem para si próprios, com o maior escrúpulo e o mais severo rigor, o propósito de evitar relações sexuais incestuosas (FREUD, 1914, p. 6).

Freud (1914) não foi o único a anunciar o totemismo, muito historiadores convergem para essa mesma história quando se trata de tribos africanas, como evidencia Amaro (2005).

\footnotetext{
${ }^{15}$ Endogamia consiste no acasalamento de animais aparentados ou, mais apropriadamente, no acasalamento de animais mais aparentados que a media da população ou de uma população base da qual não se conhece os ascendentes.
} 
La forma religiosa ${ }^{16}$ africana más arcaica es el totemismo, que prevalece, de forma pura o mistificada en todos los pueblos de África. El totemismo ha sido el que ha generado la adoración de los antepasados y a ésta se encuentra vinculada, desde tiempos inmemoriales la adoración de los muertos o manismo (Amaro, 2005, p.2).

As ideias de Freud (1914) estão em consonância com as histórias impressas em boa parte dos livros de Biologia da Evolução. Surge a duvida se foi Freud quem inspirou os primeiros Biólogos Evolucionistas a escreverem esses relatos, ou se Freud comungava das mesmas ideias dos Biólogos e baseou-se neles para escrever Totem e Tabu. Na citação a seguir, extraída de um livro de Biologia, é possível notar a semelhança de ideias:

Há cerca de 12 mil anos, o homem passava de caçador a agricultor e surgiam as primeiras civilizações. A partir daí, a evolução cultural foi responsável pela rápida aceleração das transformações humanas. Para avaliar esse desenvolvimento, basta comparar as rápidas transformações ocorridas nos últimos 10 mil anos com as lentas transformações ocorridas do australopiteco ao Homo sapiens (LINHARES, 2013, p.175).

Nas palavras de Silva Júnior (2013), também se encontra um contexto condizente com a história narrada por Freud:

Todas as populações humanas compartilharam os mesmos tipos sanguíneos no sistema $\mathbf{A B O}$ (tipos $A, B, A B$, e $O$ ), embora haja expressivas diferenças nas frequências de cada tipo especifico. [...] Muito provavelmente, isto é reflexo de uma história evolutiva para a humanidade, na qual teriam ocorrido migrações de um continente a outro e a consequente miscigenação, em maior ou menor grau, de antigas populações nativas (SILVA JÚNIOR, 2013, p. 109).

\footnotetext{
16 "A forma religiosa africana mais arcaica é o totemismo, que prevalece de forma pura ou mistificada em todos os povos da África. O totemismo tem sido o que gerou a adoração dos antepassados e este se encontra vinculada, desde os tempos imemoráveis a adoração dos mortos ou manismo."
} 
Fortes são os indícios de que a evolução do homem australopiteco em $H$. sapiens está intrinsecamente relacionada com as regras do totem ${ }^{17}$ e tabu ${ }^{18}$. Principalmente, ao que concerne a proibição do casamento entre pessoas do mesmo totem (incesto), fato que estimulou a exogamia $^{19}$.

Migração: a entrada e a saída de indivíduos de uma população também podem afetar o "estoque" de genes. Com relação a certo par de alelos, duas populações de uma mesma espécie que vivem em ambientes distintos têm, provavelmente, taxas diferentes desses genes. Se uma população receber indivíduos da população vizinha, suas taxas originais desses alelos sofrerão alteração (SILVA JÚNIOR, 2013, p.228).

Os indivíduos dessas tribos primitivas não podiam satisfazer suas pulsões sexuais com os integrantes de seu clã. Para extravasá-las, eram obrigados, pelos costumes, a casar e ter relações sexuais com membros de outros clãs, o que favorecia a mescla dos genes.

[...] [supôs-se que] a exogamia original - nos primeiros tempos e em seu verdadeiro significado - nada tivesse a ver com totemismo, mas se tivesse vinculado a ele (sem existir qualquer conexo subjacente) em uma época em que as restrições matrimoniais tornaram-se necessárias. Se bem que isto seja possível, fato é que a ligação entre totemismo e exogamia existe, sendo indiscutivelmente uma ligação muito forte (Freud, 1914, p. 7).

Fonseca (2013) afirma que casamentos consanguíneos aumentam consideravelmente a chance de nascer descendente defeituoso devido o encontro de genes raros capazes de provocar anomalias e más formações nos indivíduos. O autor ainda esclarece:

\footnotetext{
${ }^{17}$ Totem via de regra é um animal, muito raramente um vegetal ou um fenômeno natural (como a chuva ou a água), que mantém relação peculiar com o clã. Trata-se de um antepassado comum e ao mesmo tempo de um espírito guardião e protetor, que envia oráculos, perigoso para os outros e pai para os do clã. Seus filhos tem a obrigação sagrada de não matar, não comer e nem destruir o totem. Em quase todos os totens encontra-se uma lei contra as relações sexuais entre pessoas do mesmo totem e, consequentemente, contra o casamento.

${ }^{18}$ Tabu é um termo polinésio, que significa 'sagrado', 'misterioso', 'perigoso', 'proibido', 'impuro'. Traz sentido de algo inabordável, proibido e restrito que são distintas das proibições religiosas e morais, essas proibições não tem fundamento e são de origem desconhecida. Wundt $(1906,308)$ descreve o tabu como o código de leis não escrito mais antigo do homem. Aquele que infligia o tabu sofria punições terríveis.

${ }^{19}$ Exogamia é o casamento de um indivíduo com um membro de grupo estranho àquele a que pertence.
} 
Supondo que uma anormalidade recessiva ocasione o não desenvolvimento de um dos membros inferiores (ausência de uma das pernas), portanto, um padrão incomum na população (entre seres humanos). Caso seja mantido o cruzamento incestuoso (relação sexual entre familiares, com fecundação de gametas e desenvolvimento do embrião) entre indivíduos heterozigóticos para essa anomalia, a probabilidade dos descendentes manifestarem a deformidade é considerável, se comparado a um cruzamento entre entes sem parentesco. Visto que a família em questão possui o alelo recessivo (raro), e o alelo dominante é predominante na população (FONSECA, 2013, p. 1).

Segundo Futuyma (1942), na maioria dos aspectos, o Homo sapiens não é uma espécie diferente do ponto de vista da genética das populações. O autor afirma que de fato existe a presença de muitos alelos (genes) recessivos deletérios na espécie humana e que esses tem baixa frequência, como explicado anteriormente. Mas existem alguns não tão raros, de forma que, quando humanos fazem o coito com indivíduos de outras populações, as possibilidades de esses alelos surgirem nos descendentes são reduzidas; caso contrário isso não aconteça, não será difícil observar indivíduos com anomalias genéticas. "Entretanto o meio cultural por nós criado tem afetado alguns aspectos da variação genética" (FUTUYMA, 1942, p.545). O meio cultural influencia muito os humanos na escolha do parceiro sexual. Não raro para satisfazer o desejo do grupo, o homem ou a mulher casa com o cônjuge que não gostaria de ter casado. Nas tribos primitivas foi a cultura do totem quem influenciou as uniões matrimoniais evitando ao extremo o incesto entre os casais.

Homo sapiens é uma espécie cosmopolita e biologicamente única. Não existem, mecanismos biológicos de isolamento entre as populações humanas, embora ocorram frequentemente barreiras culturais ao acasalamento. Por exemplo, na Austrália são muito comuns os cruzamentos preferenciais baseados em características físicas "raciais" e, em algumas sociedades, eles têm sido estimulados por leis. Mesmo considerando-se a existência de tabus sociais contra o intercruzamento, existe um fluxo gênico considerável entre as raças (FUTUYMA, 1942, p.546). 
Futuyma entende por "raças" as diferenças físicas e biológicas apresentadas pelos humanos de acordo com sua localização geográfica. Entretanto, as diferenças não são tão grandes a ponto de originar espécies, mas são importantes e necessárias para que o fluxo gênico ocorra, e consequentemente a variabilidade, diminuindo o encontro dos alelos recessivos letais ou deletérios.

Inúmeros alelos deletérios já foram identificados por estudiosos da genética humana, alguns dos quais muito bem caracterizados bioquimicamente. [...] Para muitas dessas doenças é possível determinar se um dos genitores é heterozigoto e, assim, estimar a probabilidade de um pai em potencial vir ter uma criança afetada. $O$ aconselhamento genético de futuros pais para fornecer-lhes essas informações é uma das aplicações mais importantes da genética humana (veja Cavalli-Sforza e Bodmer, 1971). A frequência de alelos deletérios, dominantes ou recessivos, muitos dos quais impedem a reprodução ou levam à morte antes da idade reprodutiva, é bastante reduzida pela seleção natural (FUTUYMA, 1942, p.550).

Indivíduos heterozigotos ${ }^{20}$ podem ser portadores de genes letais ou deletérios, mesmo não desenvolvendo a doença, podem transferi-los a seus descendentes no caso de casarem-se com outro indivíduo heterozigoto portador do mesmo gene letal ou deletério. De acordo com a 1a lei de Mendel, da prole de tal casal espera-se uma proporção de $75 \%$ de indivíduos normais e $25 \%$ de indivíduos homozigotos ${ }^{21}$ recessivos (descendentes com genes deletérios). Se o casal for composto um indivíduo heterozigoto e o outro homozigoto recessivo (doente), a probabilidade de o descendente ser doente aumenta para $50 \%$.

Se ambos os pais forem portadores de alelos letais ou homozigotos recessivos, a probabilidade dos descendentes nascerem doentes é de $100 \%$ ! Ou seja, os portadores desses genes somente conseguiram poupar seus filhos de sua anomalia se seu cônjuge for normal portador (Aa heterozigoto) ou totalmente normal (AA - homozigoto dominante).

\footnotetext{
${ }^{20}$ Heterozigoto é quando um indivíduo tem dois alelos diferentes para determinar uma característica. Por exemplo: Aa.

${ }^{21}$ Homozigoto é quando um indivíduo tem dois alelos iguais para a determinação de uma característica. Podendo ser Homozigoto dominante, como por exemplo: $A A$, podendo ser homozigoto recessivo aa. Nesse artigo os genes ou
} 
Dessa forma, a lei de Mendel, a análise de genótipos e a lei do "totem e tabu" comprovam que quanto mais uma população de indivíduos procura casar-se com indivíduos de outra população, mais variável será o DNA dos descendentes, e assim mais genes diferentes ele terá, que podem oferecer-lhe melhor adaptação ao meio e assim colaborar para a perpetuação da espécie humana. É evidente que os atuais termos biológicos, presentes neste artigo, eram desconhecidos daqueles povos. Mas será que o instinto ${ }^{22}$ de preservação da própria espécie fez com que esses humanos abominassem a endogamia? Será que isso os levou ao ponto de matar aqueles que ousassem em burlar o totem, mantendo assim a "lei" imposta aos membros do grupo?

Se por instinto ou não, o fato é que os indivíduos que infligissem o totem enfrentavam o tabu ${ }^{15}$, ou seja, o preconceito e a perseguição de seu clã, a exclusão do grupo e na maioria das vezes a morte. $\mathrm{Na}$ analogia do Neodarwinismo, os totem e tabu enunciados por Freud (1914) serviram de Seleção Natural, evitando que genes recessivos letais se encontrassem. Os casamentos entre pessoas sem nenhum grau de parentesco próximo diminuíram consideravelmente o encontro desses alelos ou genes letais. Impressionante é constatar que tribos classificadas como "selvagens mais atrasadas e miseráveis" possam ter tido um comportamento tão benéfico para a evolução de sua espécie. É de "chamar a atenção para a grande preocupação que tem os australianos, e outros povos selvagens, com a prevenção do incesto. Tem-se de admitir que esses selvagens são mais sensíveis à questão do que nós" (FREUD, 1914, p.10).

\section{CONSIDERAÇÕES FINAIS}

Não importa o que motivou as tribos antigas a praticar a exogamia. O importante é a contribuição desta para misturar características biológicas desses indivíduos, promovendo a mistura dos genes (variabilidade gênica), dificultando o máximo possível o encontro dos genes recessivos; diversificando o DNA dos descendentes de modo que nascessem com uma boa variedade de genes; e potencializando as chances de sobrevivência, pois adquiriram características adaptáveis as

\footnotetext{
alelos letais refere-se a esses homozigotos recessivos. Na espécie humana a maioria das anomalias genéticas são causadas por alelos homozigotos recessivos.

${ }^{22}$ Instinto - É impulso natural, instinto de conservação, primeiro movimento que dirige o homem e os animais em seu procedimento. Tendência, aptidão inata. Nesse texto, a palavra Instinto foi empregada de acordo com o dicionário online da Língua Portuguesa.
} 
mais diversas situações favoráveis e desfavoráveis da natureza. Hoje em dia, o "Homem Moderno" não tem a mesma preocupação com as relações sexuais incestuosas. Isso propicia o surgimento de descendentes com genes desfavoráveis ao ambiente, o que origina uma luta incansável por sua sobrevivência, caso, é claro, esse descendente consiga nascer.

Atualmente, a Genética da Conservação é a área da Biologia que estuda as dinâmicas capazes de adaptar os indivíduos às mudanças ambientais. Outra de suas preocupações são as consequências, nas populações, de os efeitos deletérios da endogamia, que as tribos primitivas tanto lutaram para evitar (FRANKHAM, 2008 p.7). O que a genética da conservação pesquisa hoje já foi objeto da pesquisa de Freud, como exposto neste artigo. No entanto, hoje se pesquisam formas de contornar as consequências da endogamia. Muitos casais geram filhos sem saber do grau de proximidade parental que tem entre si, e outros, se sabem, não conseguem conter as pulsões sexuais que os conduzem a relacionar-se sexualmente, o que por vezes gera a concepção de indivíduos com doenças graves. O liberalismo que o Homo sapiens permitiu-se usufruir coloca em risco a manutenção da diversidade genética e desafia a Genética da Conservação e a Engenharia Genética $^{23}$ a buscarem maneiras de contornar e controlar os problemas genéticos gerados, tais como as más formações e as doenças genéticas graves.

A manutenção do tabu em relação ao incesto, por explicações biológicas, se faz explicado. Todavia, a decisão de mantê-lo ou não, cabe a cada casal, família ou clã. Sabe-se que o casamento consanguíneo aumenta as possibilidades dos descendentes nascerem defeituosos, no entanto poderão nascer filhos biologicamente defeituosos ou não. Somente os indivíduos envolvidos podem inferir sobre isso, afinal, cada pessoa sabe a energia que pulsa no interior de seu inconsciente e até que ponto vale a pena deixá-la emergir para o consciente.

\footnotetext{
${ }^{23}$ Engenharia Genética é um conjunto de técnicas que envolve a manipulação de genes em um organismo. Com o objetivo de modificá-lo, melhorá-lo para que ele possa suportar as adversidades oferecidas pelo ambiente.
} 


\section{REFERÊNCIAS}

AMARO, Cano Maria D. C. Consideraciones histórico-culturales y éticas acerca de la muerte del ser humano. Revista Cubana de Salud Pública, Cuba, v.31, no 2, p.8, abr/jun. 2005. Disponível em: <http://www.redalyc.org/articulo.oa?id=21420137014>. Acesso em: 8 ago. 2014.

BACON, Francis. Novum Organum ou verdadeiras indicações acerca da interpretação da natureza/ Nova Atlântida. São Paulo: Nova Cultural, 1999. 255p.

CAVALHEIO, Roberto; PIMENTEL, Eduardo, C. G. Endogamia: possíveis consequências e formas de controle em programas de melhoramento de bovinos de corte, Jaboticabal, 2004. Disponível em: $<$ http://www2.ufersa.edu.br/portal/view/uploads/setores/183/arquivos/ENDOGAMIA POSSIVEIS \%20CONSEQUENCIAS\%20E\%20FORMAS\%20DE\%20CONTROLE\%20EM\%20PROGRAMAS\%20DE\%20 MELHORAMENTO\%20DE\%20BOVINOS\%20DE\%20CORTE.pdf>. Acesso em: 18 ago.2014.

COLUNISTA, Portal. Variabilidade Genética. [S. I]: Portal da Educação, 2013. Disponível em: <http://www.portaleducacao.com.br/biologia/artigos/25796/variabilidade-genetica?>. Acesso em: 17 ago. 2014.

DARWIN, Charles R. A origem das espécies e a seleção natural. [1a ed 1859] 2 ed. Brasil: Hemus, 2003. 471p.

DESCARTES, René. Discurso do método. Tradução Ciro Mioranza. São Paulo: Escala Educacional, 2006. Série Filosofar. 71p.

DICIONÁRIO Online de Língua Portuguesa. Exogamia. (C) 2009-2014. Disponível em: <http://www.dicio.com.br/exogamia/>. Acesso em: 18 ago. 2014.

Acesso em: 18 ago. 2014.

Instinto. (C) 2009-2014. Disponível: <http://www.dicio.com.br/instinto/>.

FONSECA, Krukemberghe. Casamento consanguíneo. [S. I]: Brasil Escola, 2013. Disponível em:< http://www.brasilescola.com/biologia/casamento-consanguineo.htm>. Acesso em: 19 ago. 2014

FRANKHAM, Richard. Fundamentos da Genética da Conservação. Ribeirão Preto- São Paulo: Sociedade Brasileira de Genética- SBG, 2008. 280p.

FREUD, Sigmund. Totem e Tabu. In: Obras completas de Sigmund Freud; trad. Dr. J.P. Porto. Rio de Janeiro: Delta, s.d. p. 49-239. v. 14.

FUTUYMA, Douglas J.. Biologia Evolutiva. [1 1 a ed. 1942] 2 ed. Ribeirão Preto: FUNPEC- RP, 2002. $631 p$.

GRUPO VIRTUOUS. Só Biologia: Alelos Letais. [s.I.], Copyright (C) 2008-2014. Disponível em: < http://www.sobiologia.com.br/conteudos/Histologia/epitelio.php>. Acesso em: 16 ago. 2014.

LINHARES, Sérgio; GEWNDSZNAJDER, FERNANDO. Biologia hoje: Genética Evolução Ecologia. 2 ed. São Paulo: Ática, 2013. 408p.

LOUREDO, Paula. Órgãos análogos e homólogos. [S.I]: Brasil Escola, 2003.>. Acesso em: 16 ago. 2014. 
MEYER, Diogo; NIÑO, Charbel, E. Evolução: o sentido da biologia. São Paulo: UNESP, 2005. (Paradidáticos; Série Evolução). 132p. 2plts.

RODRIGUES, Paulo de Tarso Moura. Evidências da Evolução. [S. I.], [s.d] 1 imagem, 1024x523mm. Disponível em: <http://evidenciasdaevolucao.wordpress.com/evidencias-da-evolucao-2/>. Acesso em: 16 ago. 2014.

SANTANA, Ana Lúcia. Genética. [S. I.]: Info Escola, [s.d]. Disponível em: http://www.infoescola.com/ciencias/genetica/>. Acesso em: 16 ago. 2014.

SILVA JUNIOR, César da; CALDINI, Nelson Jr. Biologia 3. 10 ed. São Paulo: Saraiva, 2013. 464p.

UOL, Educação. Galileu Galilei. [S.I]:Enciclopedia Italiana di Scienze, Lettere ed Arti (Treccani), 1996-2014. Disponível em: <http://educacao.uol.com.br/biografias/galileu-galilei.jhtm>. Acesso em: 15 ago. 2014. 